\title{
【粉じん・じん脑】
}

\section{3. 回分式流動層からのダストの発生特㭠}

田中勇武，秋山高 (産医大医労衝衛生工学)

ダストの吸入による生体影響を研究する実験装置を試 作与るためには，呼気から吸入されると予测されるダス 卜を定量的に発生させる装置が必要となる。本研究に就 いては，流動化法を周いてダストを均一に発生させるこ とを試みた。まず，回分式流動尿におけるる゙スト発生の 経時的な変化特赃を調べ，次のこと学明らかにした。

1）ダストの発生速度は，時間方経過するにつれて指 数関数的に減少することが譛められた。この減少割合を ダスト発生速度係数 $(k[1 / \mathrm{S}])$ と定羲し，これについ

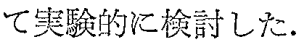

2）投入ダスト量が多くなれば，発生䟴度は大となる が，kの倠には影響しないことがわかった。

3）流㗢化用乾燥ガスの流速が堌加与れば，kの值は 流速の 2.5 乘に比例して大きくなった。

4）流動媒体量，すなふわ，砂の量が多くなれば， の值は添ぼ砂の量の 2 乘に比例して大きくなる傾向がみ ら礼尔.

5） $k$ の值は，流哠層の塔高には，影響されなかっ た.

6）発生したダストの粒径分布をアンダーセンザンプ ラーを用いて測定した結果，時間が絽過して舟粒径分布 に梳し、跡化はみられなかった。

\section{4. 溶接ヒュームに対する防じんマスクの性能} 野崎亘右（産医研）

銅柎加工の多くが，リベットによる接合から溶接の技 術に变わりつつある。これは微細な粒子であるとューム による環境の増加を意味するるのであり，呼吸保護具の 現場管理についてもまたいちだんと厳しくなりつつあ る，防じんマスクの国家倹定は，現在のところ石英粉じ んによる捕集率の値を公称值としている. そして市販マ スクの溶挍ヒュームに対する安全性の良否について，現 場からの質問もいくつかむるので，演者が行なった実験 の結果起報告し，かつマスクの使服について二，三指摘 して誩きたい。

溶接ヒュームは B-33 颠鍓居と NC-38 ステンンス用 の棒点用いて実際に溶接しながら発生したものを用い た.ヒュームのモード徍は $0.6 \mu \mathrm{m}, \mathrm{AMD}$ は $0.9 \mu \mathrm{m}$, $\sigma_{g}$ は 1.56 であった。石英粒子による致照実験とくらべ ると明らかに性能功低下し，マスクの等級に関係なく透
過率で約 $5 \%$ 低くなった. 乙かし 36 実験の相間係数は $r=0.56$ で岁り相関が悪く，捕集率低下の程度を一義 的に関係づすことはできないようである，この瑟由は 溶接ヒュームの物性が著しく不安定であるからである う．そこで高周波誘導加熱炉上り発生した鉛ヒュームに よって捕集率を测定し，石宾㕸子による捕集率とくらべ

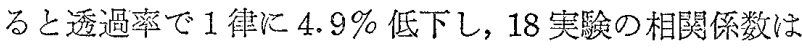
$r=0.93$ であった。この結果をもとにして捕集率に撸 算すると，公称捕集率 $99.9 \%$ のマスクはとュームでは

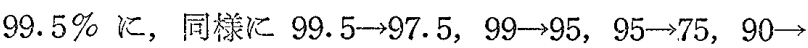
$50 ， 85 \rightarrow 25 \%$ 程度になると予想される。特級マスクで はそれ注ど捕集率が低下しないが，2級マスクでは琵し く低下することがわかった。 以上のことを念頭に招いて 現場では少なくとも 1 級以上のマスクを使用し，濾痁の

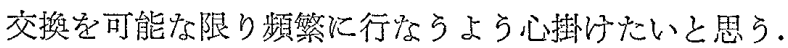

225. T.R. (total and respirable) ダストサンプラ

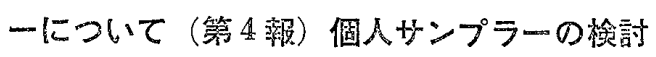
木村菊二（学研）

T.R.サンプラーは慣性衝突方式の分粒装置を装着し た濾過式捕集装畳である。すなわら気流中の粒子の慣性 うを利用して長大な粒子を衝突板（ガラス板にシリコン 油定泼く叙布したもの）上に捕え（粒径 $5 \mu \mathrm{m}$ の粒子 $50 \%, 7 \mu \mathrm{m}$ の粒子 100\%)，季た，この衝突板に衙突し ないでここを通過した微細な粒子はガラス繊維フィル ター上に捕集するようになっている，衝突板抒よびガラ ス繊維フィルターを採じん前後に积量して，その質量差 を求如引空気量で割算して，その震度学算出する，ガ ラス緒維フィルター上に捕集した粒子が吸入性汾じんで 岁り，この值に衙哭板上に捕集した粉じんを加えたのが 総粉じえである.

T.R. 個人サンプラーは採じん用のヘッドと吹引ポン プから構成されて括り，採じん用のヘッドは着用者の呼 吸面近くに固定し，吸引ポンプは腰にバンドで固定する ようになっている. 本報では, 本器の特性について基礎 的な検討を行なった結果について述べる。

まず吸引ポンプの稼動塒間について調べた結果，新し

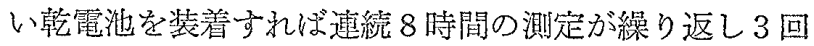
可能である。なれ吸引ポンプにダイヤフラム形式のもの を使用しているため吸引流速に脈動が屴る。この点につ いては，ヘッドの部分に適当な抵抗を挿入することによ って脈動をかなり少なくすることが可能となった。 次に多段型分粒装置付ローボリュームサンプラー，才 